\title{
Title:
}

\section{Gastric ulcer with liver penetration}

\section{Authors:}

Emanuel Dias, Hélder Cardoso, Catarina Costa, Guilherme Macedo

DOI: $10.17235 /$ reed.2022.8528/2021

Link: PubMed (Epub ahead of print)

Please cite this article as:

Dias Emanuel, Cardoso Hélder, Costa Catarina, Macedo Guilherme. Gastric ulcer with liver penetration. Rev Esp Enferm Dig 2022. doi: 10.17235/reed.2022.8528/2021.

This is a PDF file of an unedited manuscript that has been accepted for publication. As a service to our customers we are providing this early version of the manuscript. The manuscript will undergo copyediting, typesetting, and review of the resulting proof before it is published in its final form. Please note that during the production process errors may be discovered which could affect the content, and all legal disclaimers that apply to the journal pertain. 
Carta 8528 inglés

\section{Gastric ulcer with liver penetration}

Emanuel Dias ${ }^{1}$, Hélder Cardoso ${ }^{1}$, Catarina Costa ${ }^{2}$, and Guilherme Macedo ${ }^{1}$

${ }^{1}$ Gastroenterology Department and ${ }^{2}$ Pathology Department. Centro Hospitalar Universitário de São João. Porto, Portugal

Corresponding Author: Emanuel Dias

E-mail: diasj0310@gmail.com

Keywords: Peptic ulcer disease. Gastric ulcer. Liver penetration.

Financial support: the authors received no financial support for the research, authorship and/or publication of this article.

Conflict of interest: no potential conflict of interest relevant to this article was reported.

Dear Editor,

A 54-year-old male with a previous history of chronic hepatitis C complained of postprandial epigastric discomfort and weight loss. Esophagogastroduodenoscopy revealed a large gastric ulcer on the lesser antral curvature (Fig. 1A), with biopsies showing granulation tissue and inflammatory activity without other significant changes. Despite therapy with double-dose proton pump inhibitor, the symptoms did not improve and the ulcer had not healed or diminished in size at the reevaluation endoscopy eight weeks later. Biopsies were repeated and again, only revealed granulation tissue and inflammation. The ulcer was deemed medically refractory and the patient underwent a partial gastrectomy where fibrotic adhesions to liver and peritoneum were noted intra-operatively. Remarkably, macroscopical analysis of the surgical specimen revealed a hepatic fragment adherent to the ulcer and 
histopathological examination revealed epithelial loss of continuity extending to the hepatic parenchyma (Fig. 1B) and transmural fibrosis penetrating liver tissue (Fig. 1C), consistent with liver penetration. The patient improved after surgery and remains asymptomatic after two years.

Gastric ulcer penetration into the liver is a rare event, usually presenting with abdominal pain or gastrointestinal bleeding (1). The usual endoscopic appearance is a large gastric ulcer with a deep fibrin-covered base and the diagnosis is usually established by biopsies (2). Nevertheless, in our case, biopsies were performed more than once without evidence of liver tissue. A previous case that was unexpectedly found at surgery, was also preceded by endoscopy where biopsies were hard to obtain as the ulcer base was too thick (3). We can therefore hypothesize that it may be difficult to obtain adequate tissue samples of the hard liver surface with conventional biopsy forceps and endoscopic biopsies may have a low sensitivity for this complication.

In conclusion, liver penetration is a rare but important complication that must be considered in the differential diagnosis of medically refractory gastric ulcers, even in the absence of hepatic tissue in endoscopic biopsie

\section{REFERENCES}

1. Matsuzaka S, Nagai $\mathrm{Y}$, Hoshi T, et al. Visible Liver from Huge Gastric Penetration. Intern Med 2018;57(11):1667-8. DOI: 10.2169/internalmedicine.0082-17

2. Kayacetin E, Kayacetin S. Gastric ulcer penetrating to liver diagnosed by endoscopic biopsy. World J Gastroenterol 2004;10(12):1838-40. DOI: 10.3748/wjg.v10.i12.1838

3. Stylianopoulou L, Bartsokas C, Kalliakmanis V. Gastric ulcer penetration into liver: A case presentation and review of the literature. Clin Case Rep 2021;9(1):282-5. DOI: $10.1002 / \mathrm{ccr} 3.3515$ 

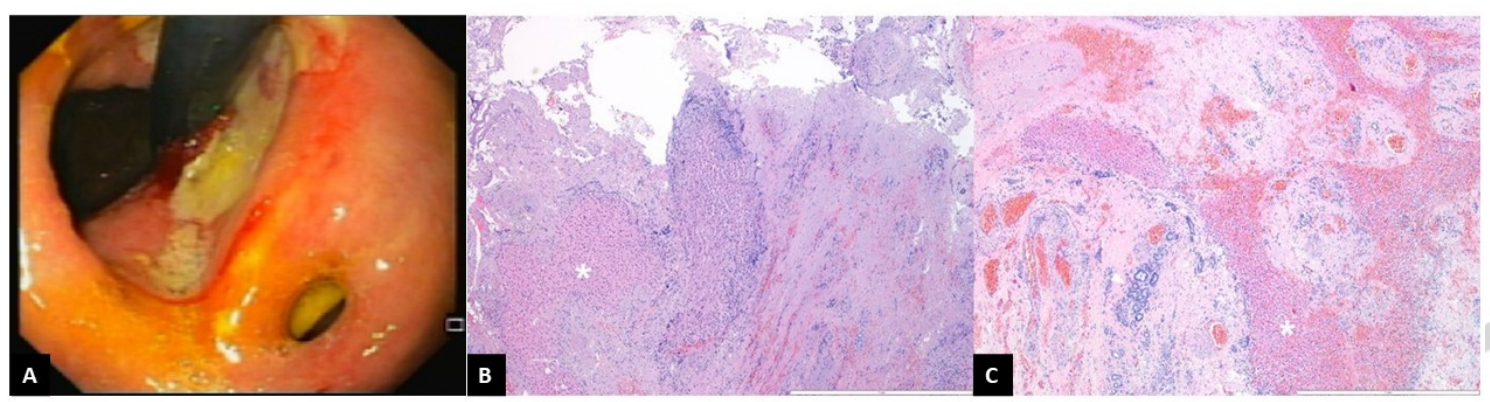

Figure 1. A. Upper digestive endoscopy revealed a large gastric ulcer $(25 \mathrm{~mm})$ at the lesser curvature of the antrum, with the base covered with fibrin. B. Histopathological examination revealed a loss of continuity of the gastric epithelium extending to hepatic parenchyma (asterisk) (HE, ×40). C. A higher amplification demonstrated hepatic tissue as groups of hepatocytes (asterisk) and biliary ducts (arrowhead) surrounded by fibrosis $(H E, \times 100)$. 